\title{
Just How Much Do We Know About Electronic Waste: Empirical Evidence from Nairobi, Kenya
}

\author{
Virginia Onyara (PhD)
}

Multimedia University of Kenya

ABSTRACT

This study aimed to find out if consumers of electrical and electronic equipment (EEE) in Nairobi, Kenya know about e-waste and its harmful effects, the available disposable mechanisms in the country and the legal framework for managing EEE. It also explored if consumers would desire to have information on e-waste and participate or be involved in its management. Primary data was collected from 98 residents of Nairobi via the online platform - SurveyMonkey tool, because the study was done during the corona virus disease (COVID-19) pandemic spread and the country was enforcing social distancing measures by the World Health Organization. Data was descriptively analyzed. Results show that majority (84.2\%) of the respondents understand what electronic waste is, $68.4 \%$ of the respondents know that e-waste has hazardous substances in them. $71 \%$ of respondents in the study however, indicated that they do not segregate it at source during disposal as is required by the e-waste guidelines. In the study, $73.7 \%$ of the respondents had no idea there existed any government efforts to guide or regulate its management. Most importantly, the city dwellers are willing to be involved in its management. This study, therefore, recommended that the government, through its regulatory bodies in environment, ICT and other relevant EEE regulators, to develop voluntary and mandatory legal, policies, guidelines and regulatory frameworks for managing EEE. The Government has to create proper disposal mechanisms, communicate effectively the challenges posed by inferior disposal methods and continuously engage the citizens in e-waste management activities. Proper disposal and its eventual management can be part of consumer's daily activity.

Key Words: E-Waste, Disposal, E-Waste Management

DOI: $10.35942 /$ ijcab.v4i1.107

\section{Cite this Article:}

Onyara, V. (2020). Just How Much Do We Know About Electronic Waste: Empirical Evidence from Nairobi, Kenya. International Journal of Current Aspects, 4(1), 43-48. https://doi.org/10.35942/ijcab.v4i1.107

\section{Introduction}

United Nations Environment Programme (UNEP) defines e-waste as old, end of life (EOL) electronic appliances that have ceased to be of any value to their owners (UNEP, 2007). Solving the e-waste problem (Step) Initiative defines it as all Electrical and Electronic Equipment (EEE) and its parts that have been discarded by its owner as waste without the intent of re-use (Step Initiative, 2019). Rapid changes in technology and the falling prices of EEE have led to an increase of EEE on the market. However, millions of tons of high-tech electronic devices are becoming obsolete each year, making e-waste one of the top environmental global challenges because these devices are composed of not only hazardous components but also valuable components. According to the Global E-waste Monitor 2017, e-waste is growing at three times the rate of municipal waste worldwide (UNU, 2017). 
Global volumes generated have been estimated at 44.7 million metric tonnes (MT), and the amount is expected to increase to 52.2 million MT by 2021, and only 20 per cent will be appropriately recycled (UNU, 2017). There has not been any recent study or reports on e-waste quantities in Kenya, equally the most recent study by United Nations University (UNU) and the International Telecommunication Union (ITU) did not reveal or approximately estimate the quantities of e-waste generated in Africa (UNU, 2017). Studies done by UNEP (2010) as reported by iHub (2014) show that Kenya generates 11,400 tonnes from refrigerators, 2,800 tonnes from televisions, 2,500 tonnes from personal computers, 500 tonnes from printers and 150 tonnes from mobile phones. Another one by Kenya ICT Action Network, as reported in the Ministry of Environment and Forestry, Draft e-waste Management Strategy (2019) shows that in 2007, 1,513 tonnes of electronics entered the Kenyan market. It also revealed that consumers are likely to dispose 1,210.4 tonnes in the second-hard market, and 18.6 tonnes to collectors or as general waste which is sent to refurbishers and recyclers. Refurbishers and recyclers then send 605.2 tonnes for final disposal. Consumer's behavior plays a critical role in the management of e-waste. How they dispose it eventually affects how the e-waste will be managed by the licensed e-waste handlers.

\section{Problem Statement}

Electronic waste has become a major global challenge because of the inadequate implementation frameworks and structures to manage it effectively. Many people are aware of the challenges ewaste poses to the environment and human health, but have no idea of the available mechanisms provided by the authorities for them to manage it properly. In some instances, lack of enforceable legal instruments has made people not to be proactive in managing it even at their own homes as they dispose it. It is not clearly known why consumers would not dispose e-waste directly to licensed e-waste handlers but studies have indicated that consumers are unaware of ewaste disposal methods available around them. In India, approximately $75 \%$ of obsolete EEE is stored due to ambiguity about how to manage them properly thus many households dispose their e-waste with regular household wastes (Ranganathan, 2018). The study shows that EEE from some institutions are disposed of at dump sites or auctioned to scrap dealers, especially when storage capacity is exhausted. Similarly, in Ghana, a large number of end of life EEE are known to be stored, mostly in houses and storage facilities, due to the uncertainty about management of their disposal, portions are sold to scavengers or get mixed with household wastes, and finally disposed of at refuse dumps (Amoyaw-Osei et al., 2011)

Kenyan regulations and guidelines by National Environment Management Authorities (NEMA) require that e-waste be segregated from other household/solid waste at source (NEMA, 2013). A vast majority of Kenyans do not know about this regulation and therefore still dispose the household waste together with the e-waste. All of these wastes eventually end up in landfills. The adverse effects of this behavior are therefore felt by the environment and human health. If consumers knew that e-waste is harmful and that there existed enforceable regulations to manage it and that the Government provided proper disposal mechanisms, then efficient and sustainable e-waste management will be achieved. Consumers of EEE will dispose the e-waste in a designated collection point where e-waste handlers would pick it and treat it in an environmentally sound manner, thus minimizing the negative effects of e-waste in the nation. 


\section{Purpose and Objective of the Study}

The primary purpose of this study was to find out if EEE consumers in Nairobi, Kenya are aware of the adverse effects e-waste to their lives and the environment. It was also prudent to find out whether consumers understand their responsibility as e-waste management stakeholders. The purpose was also to check whether government initiatives of providing information and guidance on e-waste and its management are embraced by consumers. Lastly, the study sought to find out whether or not the inhabitants of the city of Nairobi will want to be involved in the management of e-waste.

\section{Methodology, Data Collection and Data Analysis}

Due to the coronavirus disease (COVID-19) pandemic at the time of the study, data couldn't be collected using traditional data collection methods. The study was done in Nairobi, the capital city of Kenya because majority of the people in Nairobi own various categories of EEE. Data was collected using a non-probability sampling method - convenience sampling. This method of sampling relies on data collection from a population whose members are conveniently available to participate in the study. Online data collection tool - SurveyMonkey was used to develop questionnaires that were conveniently sent via smartphone to consumers in Nairobi based on their availability and willingness to take part in the study. Primary data was collected from 98 EEE consumers in Nairobi. Data was descriptively analyzed.

\section{Findings and Discussions}

Data collected was analyzed, and the results discussed in this section. Information received from the respondents fitted into the following three major categories; Knowledge of e-waste and its harmful effects, consumer responsibility in e-waste management and government efforts in the effective management of e-waste.

\subsection{Knowledge of E-Waste and its Harmful Effects}

In this study, consumers were asked if they knew what e-waste is, $84.2 \%$ of respondents said they know what e-waste is while $15.8 \%$ of respondents said they had no idea what e-waste is. A majority of the respondents were affirmative in their response; this means that, the belief that people don't know what e-waste is, is wrong. Consumers are aware that once the electronic equipment reaches its end of life, it is considered as e-waste. They were then asked whether or not they were informed that e-waste had harmful substances in it. Here also, results indicated that a majority were aware that e-waste had hazardous materials in them. $68.4 \%$ of respondents were affirmative that e-waste had harmful substances; while $31.6 \%$ had no idea that e-waste had toxic substances in them. Therefore, it is safe to mention that, consumers of EEE in Nairobi are aware of e-waste and its material composition.

They may not be aware of all the components used, but at least they know that e-waste has harmful elements in them. There are several common hazardous substances in EEE. Elements such as Lead and Mercury contaminate the soil and water when disposed of in the landfills with other waste (UNEP, 2007). These hazardous components are also listed as human carcinogens because they could damage the lungs and liver when eaten, ingested or inhaled (WHO, 2020). They also affect the growth of plants and aquatic life (UNODC, n.d.). Apart from hazardous substances, e-waste also has valuable materials like gold, tantalum, and silver and other nonhazardous components like; plastics, copper etc. Proper recycling of the precious metals 
conserves these rare earth minerals, prevents air and water pollution and reduces greenhouse gas (GHG) emissions (NEMA, 2013).

\subsection{Consumer Responsibility in E-Waste Management}

Several questions were asked to find out whether or not the respondents had an idea of what their responsibilities were in the management of e-waste. Respondents were asked to indicate where they took their e-waste once it reached its EOL and could not be used any more. Sadly, majority of the respondents $(36.8 \%)$ disposed it with their regular household waste, while $21 \%$ of respondents stored e-waste in their houses. A mere $2.6 \%$ indicated that they take it to the recycler and another $2.6 \%$ disposes it in designated drop off points. Arguably, only $5.2 \%$ of e-waste gets to be treated and managed correctly in a licensed facility. The rest of the e-waste $(94.8 \%)$ will eventually end up in the landfills and undesignated places. Table 1: shows how respondents dispose of their e-waste.

\section{Table 1: How respondents dispose their e-waste}

\begin{tabular}{|l|l|}
\hline I throw with regular household waste & $36.84 \%$ \\
\hline I keep it in a store & $21.05 \%$ \\
\hline I give to a repair shop & $18.42 \%$ \\
\hline I give to malimali (hawkers) & $18.42 \%$ \\
\hline I take to a recycler & $2.63 \%$ \\
\hline I dispose in a commercial drop off point near me & $2.63 \%$ \\
\hline My work station has drop off points, so I take there & $0.00 \%$ \\
\hline
\end{tabular}

Respondents were then asked whether during disposal, they separate their e-waste from the other household solid waste. This question was purposely added to help confirm whether the answers they would give in the preceding question were well thought before being answered; $71 \%$ of respondents mentioned that they do not separate waste at source. Only 29\% do separate. Despite having knowledge of what e-waste is, and its hazardous material composition, a vast number of respondents $(71 \%)$ still do not segregate waste. They dispose all their waste together. To find out further why they do not dispose of the e-waste as required, respondents were asked if they knew of any e-waste drop off points in their area or locality. $81.6 \%$ of respondents indicated that they have never seen any designated drop off points in their locality while $18.4 \%$ said they had seen designated drop off/ collection points in their locality.

Lack of adequate drop off points for proper disposal and collection of e-waste could partly explain why consumers of EEE in Nairobi do not dispose it safely once it reaches its end of useful life. Most of the city dwellers are aware of the harmful effects of EEE but still dispose it with other household waste that is not harmful. Because of the complicated nature of e-waste and the complex methods of handling or treating e-waste it is always required that users separate it at source so that it is not mixed with the other waste. Its treatment includes recovery of materials that could still be reused, refurbished or recycled. 


\subsection{Government Efforts}

In the study respondents were asked whether they knew of any regulations, policies or guidelines on e-waste management by EEE and environment regulators. $73.7 \%$ of the respondents had no idea there existed any form of regulations, policies or guideline by the regulators. Only $26.3 \%$ mentioned they were aware that there existed the national policy and guideline for e-waste management. They were then asked if they knew of any other government efforts in the management of e-waste. $86.5 \%$ of city dwellers who responded indicated they were not aware of any government's effort in managing e-waste, while $13.5 \%$ of respondents mentioned that they knew what the government is doing to manage e-waste. Lack of knowledge or insufficient knowledge or information on government efforts could have contributed to inferior disposal methods recorded in the study. This study reveals that city dwellers know what e-waste is, they know of its negative effects, but are not aware of any government's legislative or infrastructural efforts to manage e-waste.

\section{Conclusion and Recommendation}

Based on the findings of this study, it is commendable to note that most Nairobi residents involved in the study are aware of what e-waste is, they also know the hazardous components available in EEE that can have adverse effects on human health and environment if poorly disposed. Despite having knowledge of what e-waste is, and their hazardous material compositions they still do not segregate waste at source $(71 \%$ dispose e-waste and household waste together). The country also lacks adequate e-waste drop off points or collection centres where users can take their EEE once they reach EOL. The essence of segregating e-waste from household waste is to facilitate its treatment. E-waste is a unique kind of waste that requires a special kind of treatment that allows for the recovery of rare minerals in them and proper disposal of hazardous substances. There is already a dilemma among users of EEE when it comes to disposal. Some, dispose it with household waste, others store it, while others give them to repairers or traders. A repairer or a trader for example, after receiving e-waste from the consumer, will only take what they can use or what is important to them, and then dispose the rest of e-waste as solid waste. So, it is essential that the government provides proper e-waste bins at residential areas for disposal and also sensitize the consumers on the need to dispose it in an environmentally friendly manner. The government should provide information and proper disposal mechanisms that consumers can use for disposal. It is also important for consumers to practice good citizenship by disposing e-waste in properly designated places.

The government of Kenya has developed several tools to help in the management of e-waste. In 2013, NEMA developed guidelines (NEMA, 2013) that have been used by different stakeholders, especially recyclers and transporters, in the management of e-waste. It is worth noting that the 2013 guidelines are currently in use but as is generally known guidelines are not enforceable. Draft e-waste regulation (2013) was also developed by NEMA. This was amended in 2019 and is still in draft form awaiting parliament approval. The Ministry of Environment and Forestry has also developed e-waste strategy (Ministry of Environment and Forestry, 2019) that has gone through several stages of public participation as required by the Constitution of Kenya (Public Participation Bill, 2018). Different organizations have developed institutional policies but still, a majority of Kenyans in Nairobi, are not aware of these efforts by the government ministries, agencies and institutions. Where is the problem? Why don't residents of Nairobi know of the existing legal tools? Who is supposed to communicate to the residents? Who should coordinate government efforts to mitigate communication gaps? These are questions that future 
research should be able to unravel. Nevertheless, it is the duty of the government to protect its people by providing information, regulations and infrastructure for proper disposal of e-waste.

\section{REFERENCES}

Amoyaw-Osei, Y., Agyekum, O., Pwamang, J., Mueller, E., Fasko, R., \& Schluep, M. (2011). Ghana e-Waste Country Assessment: SBC e-Waste Africa Project.

iHub. (2014). E-waste: The Bad, The Good and The Great (Opportunities). IHUB. https://ihub.co.ke/blogs/17370/e-waste-the-bad-the-good-and-the-great-opportunities

Ministry of Environment and Forestry. (2019). National E-waste Management Strategy. http://www.environment.go.ke/wp-content/uploads/2019/05/NATIONAL-E-WASTEMANAGEMENT-STRATEGY-APRIL-29th-1.pdf

NEMA. (2013). National Environment Management Authority (NEMA)—Draft E-Waste Regulations

[Webpage]. http://www.nema.go.ke/index.php?option=com_content\&view=article\&id=35\&Itemid=1 77

PublicParticipationBill_2018.pdf. (n.d.). Retrieved April 7, 2020, from http://kenyalaw.org/kl/fileadmin/pdfdownloads/bills/2018/PublicParticipationBill_2018.p df

Ranganathan, V. (2018, June 25). Emerging Trends in Consumer Behavior and Awareness About E- Waste Disposal. Entrepreneur. https://www.entrepreneur.com/article/315672

Step Initiative. (2019). What is e-waste? - StEP Initiative [Webpage]. What Is E-Waste? http://www.step-initiative.org/e-waste-challenge.html

UNEP. (2007). E-Waste Vol. 2: E-waste Management Manual. http://wedocs.unep.org/handle/20.500.11822/9801

UNODC. (nd). Chapter 9: Illicit trade in electrical and electronic waste (e-waste) from the world to the region.

UNU. (2017). The Global E-waste Monitor 2017: Quantities, Flows, and Resources. UNU and ITU, 2017. http://ewastemonitor.info/

WHO. (2020). Electronic waste. http://www.who.int/ceh/risks/ewaste/en/

This is an open-access article published and distributed under the terms and conditions of the $(c))_{\mathrm{EY}}$ Creative Commons Attribution 4.0 International License of United States unless otherwise stated. Access, citation and distribution of this article is allowed with full recognition of the authors and the source.

Authors seeking to publish with an International Peer Reviewed Journal should consider https://www.ijcab.org/ by writing to the Editor at editor@ijcab.org. The articles must be quality and meet originality test. 